about ten times that of the ordinary emitron. As to the future, the Television Committee has announced that the present standards will remain in operation for at least three years. Any improvements during this time will not render existing receivers obsolete.

There is one aspect of television development which must be recorded with regret. At present, there seems no likelihood of international standardization with regard to definition and picture frequency standards. In the following countries the standards at the moment are as follows, although there is as yet no public service :

$\begin{array}{lcccc} & & \text { Lines per picture } & \text { Pictures per sec. } & \begin{array}{c}\text { Modulation } \\ \text { Negative }\end{array} \\ \text { Germany } & \ldots & 441 & 30 & \text { Negitive } \\ \text { France } & . . & 445 & 35 & \text { Positive } \\ \text { Tn } & 455 & 35 & \text { Positive }\end{array}$

In the distant future, international television cables may become available. In this case the absence of a common standard in European countries will be a serious matter.

In spite of these early difficulties, there is no doubt that this new development of entertainment in the home will, in the course of time, reach the same degree of importance that sound broadeasting has done; in fact it may be readily anticipated that the two services will ultimately merge.

\title{
Localization in the Central Nervous System*
}

$\mathrm{B}^{\mathrm{x}}$ electrical stimulation of the brain, David Ferrier established the main facts relating to the localization of the motor centres in the cerebral cortex. These facts have been confirmed, on man as well as on animals, and have been of great practical as well as theoretical importance. But although they have been the basis for all attempts to analyse the cerebral organization, they reveal mainly its receiving and executive apparatus and show little of the intervening processes.

With the development of methods for recording the activity of the brain in terms of the electrical effects produced, the problems of cerebral localization can be approached from another aspect. It has been found that the cerebral cortex is naturally in a state of constant activity which may take the form of a rhythmic series of potential waves (for example, Berger's $\alpha$ rhythm) or of more complex and irregular oscillations. When the activity has been reduced by an anæsthetic, the arrival of an afferent message has a twofold effect. It produces a direct local excitation in the region in which it arrives and a more widespread increase in the persistent activity of this and neighbouring regions. The latter result may be considered a local or regional awakening, for it resembles the

- Abstract of the Ferrier Iecture of the Royal Society delivered by Prof. E. D. Adrian, F.R.S., on November 10. generalized increase in electrical activity which occurs in the brain when a sleeper is roused. In either case, a mutual reinforcement by cortex and thalamus is an important factor in raising and maintaining the level of the 'spontaneous' activity.

In certain cases, electrical stimulation of the brain has the same facilitating effect as an afferent message. The spread of activity can then be followed by making simultaneous records of the potential changes at different distances from the stimulated point, and it can be shown how a number of competing wave systems can come into being.

Electrical records have not yet revealed any features peculiar to the cerebral neurones. In other parts of the nervous system there are many examples of rhythmic activity favoured by the arrival of impulses, and in the cortex, as elsewhere, there are probably all grades of spontaneity, ranging from neurone systems which cannot help discharging periodically to those which need a specific stimulus for each reaction. Thus, the activity in a given region of the cerebrum will depend on the interactions of each, rhythmic and non-rhythmic systems. In normal conditions inhibition as well as facilitation will help to determine the local patterns of activity, but in records from the narcotized brain the excitatory factors are the more prominent.

\section{International Cancer Research*} \begin{abstract}
$A$ CCOUNTS of the Second Intermational Congress Cancer which was held in Brussels in September 1936 have appeared previously in this journal (NATURE, 138,727 ; 1936. 139, 255; 1937). The second volume of publications of the Congress has now been published and contains accounts of some two hundred communications which were submitted to the Congress. The General Minutes of the Congress are to form volume 3 .

The papers are divided into two main groups : the scientific, and the social campaigns against cancer; and these groups are again divided into sub-groups.

* IInd International Congress of Scientifte and Social Campaign against Cancer. 2: Communications. Pp. xii +628 . (Bruxelles: Marcel Hayez, 1937.)
\end{abstract}

Among the papers on the social campaign are some interesting statistics of cancer in Germany, Poland, Rumania, South Africa and the Dutch Indies. It is possible to refer to only a fow of the papers in this review; emphasis will be laid on foreign scientific work, as British cancer research is often reviewed in these columns.

The first sub-group of communications on carcinogenic agents deals with the action of cancer-producing compounds, the nature of cancer viruses and the part played by hormones in the origin of cancer. Drs. J. Maisin and Y. Pourbaix describe how the production of cancer on the skin of mice by the active carcinogenic agent of tar, 3:4-benzpyrene, is inhibited by treating the animals with minute amounts 
of the oxidation products of ether. As yet the result has not been obtained with any pure compound.

Dr. N. Waterman, of Amsterdam, describes how carcinogenic agents inhibit the breakdown of cholesterol esters and possibly cause increased esterification of cholesterol in animals. The results indicate that agents which have a localized carcinogenic action may have a widespread effect in the animal. It is possible, but not certain, that general effects of this type may be an essential part of the careinogenic action. Prof. F. Vlès and Dr. A. Ugo show that if mice are injected with the fluorescent carcinogenic agent, 3:4-benzpyrene, the hair becomes fluorescent and the spectrum resembles that of the original hydrocarbon. Drs. J. G. Chalmers and P. R. Peacock show that the same compound is excreted as a fluorescent derivative in the bile. It is also excreted in some form in the urine, and thus animals excrete carcinogenic compounds by three routes, in skin fat, bile and urine, but in most cases the compound produces tumours only at the site of application and not along the paths of excretion.

Dr. Albert Fischer, of Copenhagen, reports on some interesting transplantation experiments. Tissue from salivary glands, liver, ovaries and mammary glands of young mice was grafted at a different site in the same animal from which the tissue was taken. After 10-14 days, the graft was inserted in a fresh place in the mouse, and this was repeated several times. In some cases the regrafted tissue developed into malignant tumours, showing that normal tissue may become malignant either by selection or by change in the character of the cells.

Among a number of papers on the nature of tumour viruses is one by Dr. A. Claude, of New York, showing that the virus of the Rous sarcoma No. 1 is destroyed by incubation with crystalline trypsin. Crystalline carboxypolypeptidase had no action on the virus. These results indicate that the Rous sarcoma agent is a protein. Other experimenters have found that the agent is not completely deposited on centrifuging at 15,000 R.P.M. but is completely deposited at 50,000 R.P.M.

Several communications deal with inherited predisposition and resistance to cancer. The results of Dr. Maud Slye, of Chicago, on mice breeding, indicate that types of cancer segregate as unit characters, and the incidence of malignancy at different sites can be explained by laws of heredity. Dr. N. DobrovolskaiaZavadskaia introduced radon tubes into the groins of female mice which normally had a high incidence of mammary carcinoma. The total incidence of cancer was not changed by such treatment, but one third of the tumours in the radon-treated mice were sarcomata instead of the usual mammary carcinomata.

One section of the volume deals with cancer diagnosis. Prof. P. Lamarque, of Montpellier, shows photographs of tissues made by microradiography. These are taken by placing a thin section of tissue on specially fine-grained photographic film and exposing the tissue and film to feebly penetrating $\mathrm{X}$-rays. Those parts of the tissue which contain heavy elements absorb the X-rays, and a photograph showing the distribution of heavy metals in the tissue is obtained. The results are similar to those obtained by microincineration, which shows the distribution of ash in tissues. Historadiography, however, has the advantage that the tissue is not treated so drastically as in incineration. It appears to the writer that a modification of this technique to determine the distribution of introduced radioactive elements such as radioactive phosphorus in tissues has possibilities.

The Second International Cancer Congress was well organized and the volume of "Reports" was published at the opening of the congress. The volume of communications contains many papers of value; it is unfortunate that they could not have been pub. lished immediately after the Congress. $\quad$ E. B.

\section{Iron and Steel Works Developments}

$\mathrm{I}^{\mathrm{N}}$ his presidential address to the Institution of Mechanical Engineers on October 21, Mr. David E. Roberts reviewed the changes which have taken place during the last fifty years in the basic industry of iron and steel making with which his experience has been primarily concerned. The twenty-five years preceding the Great War, when the world's annual output of steel increased from seven million to nearly seventy million tons, were marked by great activity in the development of improved processes of manufacture, and this period he regards as the one during which the greatest strides were made in the engineering side of the industry.

Sir Lowthian Bell, president of the Institution in 1884, established the ideal height for blast furnaces and, even to-day, few exceed 90 feet. In other respects, marked changes have been made. Hearths, from $11 \mathrm{ft}$. diameter, have been doubled in size while blowing pressure has increased from 5 to 25 pounds per square inch to ensure that the air will penetrate to the centre of the wider hearths. For blowing, Watt's beam engines with air cylinders 10-12 ft. in diameter are now replaced in Great Britain by turbines while, on the Continent, gas engines are largely used.
Raw materials are much more carefully selected and graded and the result is easier working of the furnace, with a saving of fuel and an increased output. Blast furnace gas, now cleansed most thoroughly, is actually cleaner than the normal atmosphere. It is used for driving gas engines or, when mixed with the richer coke oven gas, for heating and smelting operations. In the Ruhr area, with its very numerous blast furnaces and coke ovens, the whole of the works are connected to a huge pipe grid and every cubic foot of gas generated is effectively used-there is no waste such as is sometimes seen in Great Britain. Steel manufacture has also developed greatly. The Bessemer converter has returned to favour for the production of commercial steel-on the Continent it has been practically the only method of making common steel. The open-hearth process is the British mainstay and these furnaces have increased from 20 to 100 tons capacity, while some tilting furnaces of 250 tons capacity are in use. Much mechanical equipment is installed in the melting shop to increase the speed of operation and to ease the labour and exertion involved in handling vast masses of molten metal. 